\title{
Historical Research Approaches to the Analysis of Internationalisation
}

\author{
Peter J. Buckley ${ }^{1}$
}

Received: 31 October 2013/Revised: 7 May 2015/Accepted: 26 May 2015/

Published online: 29 September 2016

(C) The Author(s) 2016. This article is published with open access at Springerlink.com

\begin{abstract}
Historical research methods and approaches can improve understanding of the most appropriate techniques to confront data and test theories in internationalisation research. A critical analysis of all "texts" (sources), time series analyses, comparative methods across time periods and space, counterfactual analysis and the examination of outliers are shown to have the potential to improve research practices. Examples and applications are shown in these key areas of research with special reference to internationalisation processes. Examination of these methods allows us to see internationalisation processes as a sequenced set of decisions in time and space, path dependent to some extent but subject to managerial discretion. Internationalisation process research can benefit from the use of historical research methods in analysis of sources, production of time-lines, using comparative evidence across time and space and in the examination of feasible alternative choices.
\end{abstract}

Keywords Historical research methods - Internationalisation · Process research · Business history

\section{Introduction}

The title of this focused issue is 'About Time: Putting Process Back into Firm Internationalisation Research'. It would therefore seem obvious that historical research methods, whose primary concern is the role of time, would be at the forefront of the analysis. This is not necessarily the case, as these methods are neglected in internationalisation research, and in international business more

Peter J. Buckley

pjb@lubs.leeds.ac.uk

1 Centre for International Business, University of Leeds (CIBUL), Leeds University Business

School, University of Leeds, Leeds, England, UK 
generally. Historians face many of the same research problems that business researchers do-notably questions related to the analysis of process-but they have produced different answers, particularly in relation to the nature of causation. As a field, international business researchers need to question our research approaches more deeply.

This paper seeks to examine the types of research approaches from history that might aid in a more rounded analysis of internationalisation. Issues of sequencing, path dependence, contingent choices and the evaluation of alternatives are all critical in the internationalisation process and are grist to the mill of historical research. An examination of historical research methods leads to a new approach to the concept of internationalisation itself.

\subsection{Historical Research Approaches: The Challenge of Different Underlying Philosophies}

It is the difference in underlying philosophy between history and social science that presents the keenest challenge in integrating the temporal dimension with international business research. The contrast between the philosophy underlying history and that of social science-an issue for over a century (e.g., Simiand 1903)_is put by Isaiah Berlin:

History details the differences among events, whereas the sciences focus on similarities. History lacks the sciences' ideal models, whose usefulness varies inversely with the number of characteristics to which they apply. As an external observer the scientist willingly distorts the individual to make it an instance of the general, but the historian, himself an actor, renounces interest in the general in order to understand the past through the projection of his own experience upon it. It is the scientist's business to fit the facts to the theory, the historian's responsibility to place his confidence in facts over theories (Berlin 1960, p. 1 (Abstract). ${ }^{1}$

Gaddis (2002) suggests that a particular contrast between history and social science is that history insists on the interdependence of variables, whilst mainstream social science methods rely on identifying the 'independent variable' which affects (causes) changes in dependent variables (Gaddis 2002, particularly Chapter 4). He suggests that this parallels the distinction between a reductionist view and an ecological approach (2002, p. 54), and that this arises from the social scientists' desire to forecast the future (2002, p. 56). This also implies continuity over timethe independent variable persists in its causative effect(s). It is also connected with assumptions of rationality, which also is assumed to be time-invariant. Social scientists would counter that historians are theory resistant, at least to the kind of

\footnotetext{
1 It is suggested by Cannadine (2013,p. 9) that academic histories are often responsible for emphasising divergences rather than similarities: 'Most academics are trained to look for divergences and disparities rather than for similarities and affinities, but this relentless urge to draw distinctions often results in important connections and resemblances being overlooked'. The contrast between history and social science has been an issue for over a century (see Simiand 1903).
} 
independent variable/rationalist/context-invariant reductionist theory that (perhaps stereotypically) characterises economistic approaches.

Compromises are possible. Recognising sensitive dependence on initial conditions brings 'narrative' and 'analysis' much closer together, as does dividing time into manageable units-perhaps 'short-term and long term' or 'immediate, intermediate and distant' (Gaddis 2002, p. 95). Causality, interdependence, contingency and moderating variables are more manageable when the time-frame is defined. Research in history therefore demonstrates the importance of time, sequencing and process. It also highlights the role of individuals and their decision making. These elements are particularly important in examining entrepreneurship and individual (manager's) decisions and their outcome in contexts such as the internationalisation of the firm. ${ }^{2}$

How, then, would we recognise if genuinely historical work had been accomplished in internationalisation studies (or indeed in any area of the social sciences)? Tilley (1983, p. 79) gives us an answer:

By 'genuinely historical', I mean studies assuming that the time and place in which a structure or process appears makes a difference to its character, that the sequence in which similar events occur has a substantial impact on their outcomes, and that the existing record of past structures and processes is problematic, requiring systematic investigation in its own right instead of lending itself immediately to social-scientific synthesis.

History matters - the importance of historical effects in international businessis illustrated by Chitu et al. (2013), who document a 'history effect' in which the pattern of foreign bond holdings of US investors seven decades ago continues to influence holdings today. Holdings 70 years ago explain $10-15 \%$ of the crosscountry variation in current holdings, reflecting the fixed costs of market entry and exit together with endogenous learning. They note that fixed costs need not be large to have persistent effects on the geography of bilateral asset holdings - they need only to be different across countries. Evidence was also found of a 'history effect' in trade not unlike that in finance. The history effect is twice as large for non-dollar bonds as a result of larger sunk costs for US financial investments other than the dollar. Legacy effects loom large in international finance and trade.

It is argued in this paper that time and place (context) do make a difference to the structure and process of an individual firm's internationalisation, that past structures and processes do influence outcomes and that proper acknowledgement of context is vital in understanding and theorising internationalisation. It is further argued that attention to these issues leads to a new conception of internationalisation.

\section{Research Methods}

Reflecting on the purpose of his methods in his book Bloodlands, on Eastern Europe in the period 1933-45, the historian Timothy Snyder (2010, p. xviii) states that:

$\overline{2}$ See also the debate on the 'historic turn' in organisation studies (Clark and Rowlinson 2004). 
...its three fundamental methods are simple: insistence that no past event is beyond historical understanding or beyond the reach of historical enquiry; reflection upon the possibility of alternative choices and acceptance of the irreducible reality of choice in human affairs; and chronological attention to all of the Stalinist and Nazi policies that labelled large numbers of civilians and prisoners of war.

This paper follows similar principles. These are: (1) that the methods of history are appropriate to the study of the internationalisation of firms; (2) that choices and alternatives at given points of time are central to this process; (3) that the role of sequencing and time are central; and (4) that the comparative method is an aid to comprehension of the process of internationalisation.

This paper now examines research methods widely used in history ${ }^{3}$ that have the capability to improve international business research. These are: (1) source criticism (here it is argued that international business researchers are insufficiently aware of deficiencies in "texts"); (2) the analysis of sequences, including time series analyses and process theorising; (3) comparative methods (not exclusive to historical research); and (4) counterfactual analyses (which are currently less utilised than in previous periods of international business theorising). This followed by a proposed research agenda based on the two key methods of examining change over time and utilising comparative analysis.

\subsection{Source Criticism}

The use of sources is as prevalent in international business as in history but they are often accepted uncritically. Gottschalk (1950), noting that few source documents are completely reliable, suggests that, 'for each particular of a document the process of establishing credibility should be separately undertaken regardless of the general credibility of the author'. Given that reliability cannot be assumed, source criticism, as Kipping et al. (2014) argue, is fundamental to any historical research.

The trustworthiness of an author may establish a basic level of credibility for each statement, but each element must be separately evaluated. This requires questioning the provenance of the text and its internal reliability (Kipping et al. 2014) - including, importantly, attention to language translation issues if relevant. This leads to the important checks brought about by triangulating the evidence. Triangulation requires the use of at least two independent sources (Kipping et al. 2014). This principle is utilised in international business journals by the requirement that both elements of a dyadic relationship are needed to cross check each other. Examples include licensor and licensee, both partners in a joint venture, parent and subsidiary in a multinational enterprise. The question of how far these are independent sources also needs careful investigation. Documents or statements

\footnotetext{
3 Stephanie Decker (2013, p. 6) identified four features that 'clearly distinguish historical from nonhistorical research designs'. These are: reconstruction from primary sources (empirical rigour), thick contextualisation in time and space (empirical at times, theoretical rigour), periodization (theoretical rigour when combined with strong historiography) and historical narrative (accessibility, empirical and theoretical rigours).
} 
addressed to different individuals and institutions may serve a variety of purposes. Those addressed to powerful individuals, groups or institutions may be intended for gain by the sender. Interviews may be designed to impress the interlocutor. The purpose of the document needs to be explicated. Documents may be designed for prestige, tax minimisation, satisfaction of guarantees (by government, sponsors or creditors) or to cover deficiencies in performance. The historian's craft is, in part at least, to expose fraud and error (Bloch 1954).

Source criticism includes evaluating what is not present in archives, not just what is. Jones (1998) points out that the company archives many analysts require often do not survive-those that involve statutory obligations often do, but those involving high-level decision making, such as Board papers, often do not. He points out that 'issues of capabilities, innovation and culture will necessitate looking at what happens "lower down” within a firm's structure' (Jones 1998, p. 19). Further,

The study of intangibles such as the knowledge possessed within a firm, flows of information, and the corporate culture-and how all these things changes over time can involve a very wide range of historical record far removed from documents on strategies... Oral history-of staff employed at all levels—is of special use in examining issues of culture, information flows and systems (Jones 1998, p. 19).

These issues-intangible assets, strategy, culture and decision making in the face of imperfect information-are crucial in international business strategy research.

In addition to criticisms based on material that exists in 'the archive', we need to recognise that the archive is the result of a selection process and therefore that excluded material may be important. ${ }^{4}$ The selection process may be biased towards particular nations, regions, races, classes, genders, creeds, political groupings or belief systems. This is a key theme of 'subaltern studies' growing out of South Asia, and particularly India, in imperial times (Ludden 2001). The clear implication of these studies is that the colonial era archive was compiled by the colonial (British) administrators and this presents a largely pro-Imperial bias. However, it is also true that among the dispossessed voices, some were privileged (e.g., the Congress Party spokespeople) and others selected out. The lineage of subaltern studies leads us through Gramsci (1973) to postmodern views of the text: Derrida (1994), Foucault (1965), Barthes (2005). As well as not 'hearing' particular groups, the archive records may not cover particular questions or issues ${ }^{5}$ (see also Belich $2009^{6}$; Decker 2013; Moss 1997).

\footnotetext{
${ }^{4}$ For an excellent review of the use (and extension) of archive material see Wilkins and Hill (2011) 'Bibliographical Essay' pp. 445-458.

5 See also Schwarzkopf (2012).

6 Belich notes, of trying to identify 'emigrants' and their opinions: 'This problem of the silent majority is, of course, endemic in the social history of ideas. The standard solution, not one to be despised in the absence of alternatives, is to pile up available examples of opinions in the vague hope that these are typical. Once possible refinement is the analysis of the conceptual language of substantial groups of lesser writers who are trying to persuade their still-larger target audience to do something' (Belich 2009, p. 148 f.).
} 


\subsection{Analysing Sequences, Time Series and Processes}

There are a number of important techniques in historical research which are useful to international business scholars in examining process, sequence, rhythm and speed-all of which are important in internationalisation. As Mahoney points out (2004, p. 88), 'Causation is fundamentally a matter of sequence'. This is a problem addressed in economics as 'Granger causality' (1988). The critical question is not data access, but careful theorising. Sequence and duration arguments attempt to pick up sensitivity to time and place.

Process analysis holds out the possibility of integrating the time dimension into the internationalisation of firms. Process research, which is contrasted to "variance paradigms', pays particular attention to the sequencing of events that take place within cases (Welch and Paavilainen-Mantymaki 2014). Events, not variables, are the crucial writ of analysis and capturing multiple time points builds narrative, event studies and panel data analyses. In combination with variance approaches, process analysis has the potential to explain the effects of context (place) and time in internationalisation. The critical task is the identification of the linking mechanisms that connect cause and effect. This requires connecting qualitative data evaluation with experimental reasoning. It is also a useful check on spurious statistical relationships (Granger and Newbold 1974). Easterlin (2013) argues that crosssectional relationships are often taken to indicate causation when they may merely reflect historical experience, i.e., similar leader-follower patterns for variables that are causally unrelated. This is particularly the case when similar geographic patterns of diffusion are captured by the data - as may well be the case when studying the internationalisation of firms. This may reflect the fact that one set of (national) firms get an early start whilst others play catch-up.

We must, however, beware of 'ingrained assumptions about historical periodization where mere temporal succession is insufficiently distinguished from historical explanation' (Gregory 2012, p. 9). This provides a connection to 'path dependence' and sensitivity to initial conditions. Careful examination of relevant data allows analysts to identify reactive sequences "whereby an initial outcome triggers a chain of temporally ordered and causally connected events that lead to a final outcome of interest' (Mahoney 2004, p. 91).

Page (2006), however, shows that path dependence describes a set of models, not a single model. Forms of history dependence can be divided between those where outcomes are history dependent and those in which the equilibria depend on history. Path dependence requires 'a build-up of behavioural routines, social connections, or cognitive structures around an institution' (p. 89). Page shows that there is a variety of types of path dependence, each of which can be precisely defined, and that it is insufficient to cite 'increasing returns' as evidence of path-dependent processes. The consequences for process research on internationalisation are profound and require researchers to be as precise as possible, when asserting path dependence, to evidence its roots and specify their impact on future trajectories. Jackson and Kollman (2010) build on Page's definitions and suggest 'If social scientists use notions of path dependence, they should have clearly articulated definitions and criteria for what constitutes a path dependent process' (p. 258): 'Any such 
formulation must be able to explain how the effects of initial and early outcomes are maintained over long periods of time and continue to be observed in current outcomes' (p. 280). This is far stronger than a simple statement that 'history matters'. Path-dependent sequences raise important theoretical issues and thereby contribute to a further and deeper round of understanding; as with quantitative analysis we need to be constantly attentive to sources of bias (Nickell 1981).

Understanding sequences entails additional complexities. Brown (2012, p. xxii) points out that choosing the periodicity (start and end points of data collection and investigation) can risk coming to foregone conclusions and 'a deceptive teleology':

Two aspects of history are particularly important for historians: propulsion and periodization. The first concerns the forces that promote change. The second involves mental architecture: the chronological framework within which we set out history. Since all periodization presumes a theory of change, these are linked theoretical properties (Green 1993, p. 17).

Propulsion and periodization-change and classification-are ultimately constructs and need to be placed both within a theoretical framework and a given context of time and place. This is a challenge to international business research which is often insufficiently theoretical and contextualised.

International business studies need to be sensitive to the period of study. Laidler (2012, p. 5) advises,

The past may be the only source of data against which economic hypotheses can be tested or calibrated, but data never speak entirely for themselves. They need to be interpreted through a theory. When the only theory deemed suitable for this purpose embodies itself as part of its own structure, even on an 'as if' basis, then that structure is inevitably projected onto the past, and other perspectives on the historical record are obscured.

This suggests that a fundamental problem is that international business research is often inadequately theorised. Theories which stand up to testing in many historical periods are more robust than those that do not. Jones and Khanna (2006, p. 455) see history as an important source of time series data: 'historical variation is at least as good as contemporary cross-sectional variation in illuminating conceptual issues'. Although it should be noted that many historians are sensitive to the limits of generalisation across historical periods. Burgelman (2011) sees longitudinal qualitative research being situated between history as 'particular generalization' (Gaddis 2002) and reductionism; that is, 'general particularization'.

Longitudinal research and good process research draw on both history's narrative methods and statistical and mathematical models. Such longitudinal studies clearly need rigorous methods from both history and statistics. A relevant example is Kogut and Parkinson (1998), who examine the adoption of the multidivisional structure, testing Chandler's (1962) core thesis over a long time period, 'analysing history from the start'. Despite the difficulties of compiling archival data for a large sample of firms, the authors are able to test an innovative methodology on diffusion histories of the 'M-form' from the period beginning in 1950. They use a hazard model (of adopting the M-form) with imitation and firm covariates that predict 
adoption rates. The sample (62 firms) is large enough to be split into 'fast' and 'slow' adopters of this organisational innovation and a comparison of the difference between the two samples enables the authors to confirm Chandler's historical account and to point to some qualifications concerning flows of information between firms which meant that proximate firms were more likely to adopt the M-form structure. Imitation effects by firms located in the same industry and firms with links to M-form adopters also seemed significant.

The Kogut and Parkinson (1998) study is a successful example of 'History Meets Business Studies' (p. 257) and also of the application of techniques of organisational demography. This approach has also been successfully applied to the birth and death of subsidiaries and foreign market entry strategies (Kogut 2009). Historical studies have established an important precedent of 'the importance of sampling on founders rather than survivors and of the effects of age on mortality' (Kogut 2009, p. 721). Shaver (1998) pointed out that many previous studies had not accounted for endogeneity and were subject to self-selection bias but that such effects could be corrected for using a methodology that factors in the full history of entries, taking account of strategy choice based on firm attributes and industry conditions. Strategy choice is endogenous and self selected based on these conditions and modelling has to account for this. Concepts such as the 'liability of newness' (Stinchcombe 1965) and the (in International Business) celebrated 'liability of foreignness' (Zaheer 1995 after Hymer 1976) examine diffusion over time. There are, however, as Kogut (2009) points out, several unresolved challenges in the organisational demography literature. First, self-selection bias is still unresolved in that successful firms are more likely to venture abroad. Second, because of unobserved variables (such as the quality of the firm) heterogeneity remains in any sample of firms and any heterogeneous population can be shown to suffer 'liability of newness'. Controls for heterogeneity, of course, are a palliative (e.g., size of firm) but it is difficult to control all such variation. A careful specification of the growth process of firms (despite Penrose (1959) and her heirs) still eludes us.

In concluding this section, it should be mentioned that cliometrics, or the measurement of history (also called the New Economic History) is not uncontroversial (Diebolt 2012). 'Hypothetico-deductive models' (utilising the counterfactual position) using 'propositions contrary to the facts has not escaped criticism' (Diebolt 2012, p. 4), and they contrast with the inductive position of the German historical school (Grimmer-Solem 2003). The economistic tradition of 'opportunity cost' whereby the true costs of any action is the best alternative foregone, provides a firm philosophical link between economics and the counterfactual as discussed below.

\subsection{Comparative Methods}

The comparative method is of great importance throughout the social sciences. There are three classic comparators in social science research: across space, across time, and against a carefully specified counterfactual state of the world (Buckley et al. 1992). International business research has traditionally focused on just one of these-across space. Historical research specialises particularly in comparisons 
across time, but also has lessons in spatial comparison and in counterfactual analysis.

Research that depends on ex post statistical adjustment (such as cross-country regressions) has recently come under fire; there has been a commensurate shift of focus towards design-based research-in which control over confounding variables comes primarily from research design, rather than model-based statistical adjustment (Dunning 2012, p. xvii).

The design of a randomised controlled experiment has three characteristics (Freedman et al. 2007, pp. 4-8):

1. The response of the experimental subjects assigned to receive a treatment is compared to the response of subjects assigned to a control group. This allows comparisons of outcomes across the two groups.

2. The assignment of subjects to treatment and control groups is done at randoma coin toss, for example. This establishes ex ante symmetry between the groups and obviates the existence of confounding variables.

3. The manipulation of the treatment or intervention is under the control of the experimental research. This establishes further evidence for a causal relationship between the treatment and the outcomes (Dunning 2012, p. 15).

Crucially most extant research utilises 'as if random' assignment of interventions rather than 'natural'. Its success depends upon the plausibility of 'as if random', the credibility of models and the relevance of intervention. 'Qualitative evidence plays a central role in the analysis of natural experiments' (Dunning 2012, p. 228). This is because an investigation of the causal process is critical (Collier et al. 2010) in avoiding 'selecting on the dependent' variable by analysing only those cases where causal-process observations appear to have played a productive inferential role. Indeed, Dunning (2012, p. 229) suggests that a future research agenda should focus on developing a framework that distinguishes and predicts when and what kinds of causal-process observations provide the most useful leverage for causal inference in natural experiments. Results however may be very particular and parochial because of the limited availability of natural experiment possibilities (Yin 2014). Experimental results, therefore, come at a price.

The price for success is a focus that is too narrow and too local to tell us 'what works' in development, to design policy, or to advance scientific knowledge about development processes (Deaton 2009, p. 426).

Comparison across places by geographic area or space is frequent in international business research (across nations, cultures, regions, areas, cities). The multinational enterprise is an excellent laboratory or natural experiment because it holds constant the single institution of the firm but varies the location of study. The division, and the later unification, of Germany allowed Kogut and Zander (2000) the opportunity to conduct a natural experiment by comparing the two sections of the Zeiss Company under socialism and capitalism. The experimental design measured the dependent variable (outcome) — the technological output of the two firms proxied by 
patents - under 'treatments' offered by the different economic contexts of the two different economic systems. This unusual design substituted for a random sample by eliminating the effects of extraneous factors and isolating the effects of the treatment variable on the 'same' firm. Comparative management experiments can be done by comparing company A's subsidiary in Vietnam with its subsidiary in Virginia. This is the stock-in-trade of many international business experiments and was utilised by Hofstede (1991, 1997, 2001), whose work on culture held the host company (IBM) culture constant whilst varying the purported national cultural responses of the firm's employees.

Comparisons across time, holding place constant, are the essence of 'history'. They give rise to notions of 'growth', 'progress', 'design', 'loss'. Chandler (1984) describes his method as the comparison of detailed case studies to generate 'non historically specific generalizations'. Research in business history has challenged the Chandler thesis that managerial capitalism is universally becoming the norm (Whittington 2007; Rowlinson et al. 2007). Hannah (2007) illustrates the use of comparative historical data to challenge the received wisdom. As noted elsewhere in this piece, such comparisons are fraught with danger unless carefully conducted. Meanings of documents, words, artefacts and statements vary according to different point of time usage and must be carefully analysed as best practice historical research dictates. As Ragin says (1987, p. 27),

many features of social life confound attempts to unravel causal complexity when experimental methods cannot be used... First, rarely does an outcome of interest to social scientists have a single cause... Second, causes rarely operate in isolation. Usually, it is the combined effect of various conditions their intersection in time and space, that produces a certain outcome... Third, a specific cause may have opposite effects depending on context.

These three factors-multiple, interacting causes, differential by context-are the very essence of international business research. Because of the difficulty of designing natural experiments International business research has emphasised statistical control in its methods. Ragin (1987) points out that statistical control is very different from experimental control. ${ }^{7}$ Statistical control does not equate to experimental control: 'the dependent variable is not examined under all possible combinations of values of the independent variables, as is possible in experimental investigations' (Ragin 1987, p. 61). Ragin presents a Boolean approach to qualitative comparison (after George Boole (2003) [1854] and also known as the algebra of logic or algebra of sets). Kogut (2009) shows the relevance of this approach to international business research (see also Saka-Helmhout 2011). A recent development of the use of Boolean algebra in international business is the

\footnotetext{
7 'In most statistical analyses, the effect of a control variable is its average effect on the dependent variable, across all cases, not of the effects of other variables. The subtraction of effects central to statistical control is a purely mechanical operation predicted on simplifying assumptions. It is assumed in multiple regression, for example, that a variable's effect is the same in each case - that a one-unit change in an independent variable has the same effect on the dependent variable regardless of context, that is, regardless variable's effect by simple subtraction. The result is a dependent variable whose values have been "corrected" for the effects of one or more independent variables' (Ragin 1987, p. 59).
} 


$\begin{array}{llll}\begin{array}{l}\text { Condition } \\ \text { A }\end{array} & \text { B } & \text { C } & \begin{array}{r}\text { Outcome } \\ 1 \text { or } 0\end{array} \\ 0 & & 0 & 0 \\ 0 & 0 & 1 & ? \\ 0 & 0 & 0 & ? \\ 1 & 1 & 0 & ? \\ 1 & 0 & 0 & ? \\ 1 & 1 & 1 & ? \\ 0 & 0 & 1 & ? \\ 1 & 1 & 1 & 1\end{array}$

Fig. 1 Truth table for a three cause proposition

application of fuzzy-set qualitative comparative analysis in the assessment of different models of capitalism (Judge et al. 2014).

Qualitative comparisons are of the essence in (historical) international business research. As Kogut (2009) shows, a proposition based on a three-cause explanation in order to avoid simplifying assumptions at the outset requires a truth table of $2^{3}$ or eight combinations as in Fig. 1. Thus, to achieve experimental control, the investigation needs eight cases with the characteristics shown in the table in order to determine which combination of causes (A, B, C) determines the outcome (1). (See Ragin 1987, particularly Chapters 7 and 8.) Thus historical comparative data can focus our attention on cases as wholes and to explore the combinatorial complexities of causation (Ragin 1987, p. 171). ${ }^{8}$ It is also suggestive of the answer to the perennial question of how many cases are needed to satisfy a proposition. For instance, it might be suggested that the rise of Japan was due to (1) lifetime work contracts, (2) company unions and (3) the Keiretsu system. In order to prove or disprove the argument, the bottom line where all three proposed casual factors are present must be contrasted with situations where none of them are present (the top line) where only one of the proposed causes is present and where combinations of two causes are present. This enables the analyst to identify necessary and sufficient conditions. In a three cause theoretical proposal, a total of eight cases are needed.

As Mahoney (2004, p. 82) says, 'comparative-historical methodology offers tools well adapted to the analysis of necessary and sufficient causes'. This need not rely on deterministic logic because necessary and sufficient causes can be expressed in a probabilistic framework. This also aligns with expressing variables in a continuous rather than in a dichotomous fashion. These techniques are helpful, as SakaHelmhout (2011) points out, in analysing cross-case analyses of bundles of conditions, in particular in the identification of patterns of regularities and differences. The methodological stream (and theoretical underpinnings) of comparative historical research therefore lead to the more systematic pinpointing of necessary and sufficient causes in international business case research. For applications to management research, see Oz (2004).

\footnotetext{
${ }^{8}$ For a full discussion of varieties of comparative history, see Skocpol and Somers (1980).
} 


\subsection{Counterfactual Analysis}

The third classic comparator is the 'alternative position'. The counterfactual question-'what if?'-is a particular type of thought experiment designed to elucidate causality. It is widely (if sometimes unwittingly) used in economics where 'opportunity cost' (the real cost of resources) is defined as the cost of the next best alternative foregone. The 'alternative position' and its specification have long been a particular problem in international business research-classically in the analysis of foreign direct investment (FDI). What would have happened in the absence of a particular foreign investment? (Reddaway et al. 1968; Steuer 1973; Cairncross 1953; Buckley et al. 1992, p. 36). Jones and Khanna (2006, p. 464) say that a 'comparative approach also gets at the spirit of specifying counterfactuals'.

Historians have long had to face this issue. Several variously sophisticated attempts have been made to try to answer the question of what would (might) have happened had some of the crucial turning points of history turned out differently (Beatty 2011; Ferguson 1997; Cowley 1999; Lebow 2014). Lebow (2012) points out that counterfactuals are frequently used in physical and biological sciences to develop and evaluate sophisticated, non-linear models. The counterfactual has to be well defined and this requires a thorough analysis and presentation of the context of the alternative position. Such thought experiments are perhaps history's closest comparator to a laboratory experiment (Gaddis 2002, p. 100)—although see the section on natural experiments in the social sciences above. The counterfactual counteracts the static nature of much historical analysis by focusing upon dynamics and processes.

Durand and Vaara (2009, p. 1245) have examined the role of counterfactuals in explicating causality in the field of business strategy. They argue that:

Counterfactual history can add to our understanding of the context-specific construction of resource-based competitive advantage and path dependence, and causal modelling can help to reconceptualize the relationships between resources and performance.

The role of counterfactual reasoning in organisation studies was also explored in two issues of Management \& Organizational History [volume 3(1) 2008 and volume 4(2) 2007]. MacKay (2007) pointed out that counterfactuals can guard against path dependencies in both structure of organisations and perception. Counterfactuals illustrate that the world could be other than it is and help the analyst to evaluate different possibilities including decisions and their outcomes. Thus socio-economic and technical path dependencies can introduce rigidities and cognitive or psychological path dependencies can impair organisational learning. Toms and Beck (2007) criticise received counterfactuals (on the Lancashire cotton industry) as suffering from the problems of teleology and hindsight that occur when the counterfactual is contaminated by ex post knowledge of the outcome (Maielli and Booth 2008). ${ }^{9}$ Toms and Beck (2007, p. 315) attempt to construct a history 'from the perspective of decision making entrepreneurs as embedded historical

\footnotetext{
${ }^{9}$ See Evans (2014) for a critical appraisal of counterfactuals.
} 
actors'. This is surely the model for internationalisation researchers, when examining past decisions and their outcome.

The key, as Leunig (2010) points out, is to be explicit in specifying the counterfactual position as this provides more evidence than a simple judgement on the impact of (say) a critical innovation. Fogel (1964) in finding that agricultural land opened up by the railroads might otherwise have been undeveloped, examined the possibility of an alternative network of canals. ${ }^{10}$ This was done not by simple perusal of a map but by examining detailed typographical maps, as a canal builder would do. A limitation of counterfactual analysis is the ability to go on to use comparative analysis because the carefully constructed counterfactual is often locationally or temporally specific. For instance, although in Fogel's counterfactual, canals could have done most of the work of railroads, he assumed away the vagaries of the weather-in the Northeast of the US at least, canals would have been frozen for at least 4 months of the year. ${ }^{11}$ An excellent example of a carefully constructed counterfactual is Casson's construction of the (optimal) counterfactual railway network (complete with timetable) for the UK taking account of network performance, the physical geography of the UK, Victorian urbanisation and traffic, engineering constraints, regulation, institutional and political constraints (Casson 2009).

The counterfactual has an important place in the development of international business theory as analyses of the impact of FDI on host and source countries have been cast in the terms of the 'alternative position'-what would have happened in the absence of FDI. Foreshadowing the current debate an offshoring and outsourcing, earlier literature on the impact of FDI following Hufbauer and Adler (1968) identified three polar 'alternative positions' (Buckley and Artisien 1987, pp. 73, 78-79, 80).

The classical assumption assumes that FDI produces a net addition to capital formation in the host country but a similar decline in capital formation in the source country. This is equivalent to the assumption that FDI substitutes for exports. The reverse classical assumption assumes that the FDI substitutes for investment in the host country but leaves investment in the source country unchanged. This is equivalent to 'defensive investment' where the source country firm cannot penetrate the target market via exports and would lose the market to host country firms in the absence of FDI. The anti-classical assumption is that FDI does not substitute for capital investment in the source country, neither does it reduce investment by host country firms. Consequently FDI increases world capital formation (in contrast to the other two assumptions where world capital formation is unchanged).

Anticlassical conditions are most likely when host country firms are incapable of undertaking the projects fulfilled by FDI. Each of these assumptions is static and rigid — not allowing for a growth of demand, perhaps from the 'presence effect'. An organic model, postulating that FDI substitutes for exports in the short run, but in the long run substitutes for rival investment is more likely. Hood and Young (1979)

\footnotetext{
${ }^{10}$ As a referee points out, Fogel was not posing the 'what if' question but rather 'by how much less would the US economy have grown if there had been no railways'.

11 I owe this point to Geoff Jones (personal communication 09.07.2013).
} 
pointed out that the relationship between FDI and exports needs to be fully specified in any such examination of effects of FDI.

This debate needs to be updated as it predated studies of MNEs' foreign market servicing strategies and motives other than market-seeking. A parallel move away from economic counterfactuals towards specifying alternative decision making scenarios for decision-making entrepreneurs would be a step forward here (Toms and Beck 2007). A further important question here concerns the identity of the decision maker and whether ownership (foreign versus domestic) matters. As concern with the employment impact of FDI at home and abroad grows, counterfactual analysis is useful in specifying the myriad impacts (employment among them) of modern MNEs.

The 'historical alternatives approach' (Zeitlin 2007) is a specifically business history variant of counterfactual analysis. The historical alternatives approach is promoted by Zeitlin (2007) as 'against teleology and determinism'. The approach suggests that plasticity of technology has been underrated, leading to technological determinism of a particularly narrow type. Strategic action in the face of uncertainty, mutability and hedging strategies gives a far wider range of outcomes than conventionally allowed for and 'the market' is dogmatically and narrowly the result of historical construction. Size of firms, strategic action, industry imperatives and rationality are too glibly taken as determining factors and the result is an excessively pre-determined view of business choices. While it is certainly the case that many analyses based on historical reasoning are unduly constrained in terms of other potential outcomes, alternative futures have to be specified extremely carefully and constraints that are to be lifted on outcomes must be spelled out and the degree to which they are assumed to be not binding requires extensive and meticulous research.

In internationalisation research, alternative positions are important concepts in the development of the process. The decisions that key managers make can be evaluated by presenting them with alternative scenarios, as Buckley et al. (2007) did. This is usually, for practical and cost reasons, a point-of-time rather than a continuous exercise even though, in principle, these choices could be presented to managers frequently throughout the internationalisation process. There are examples of where a single investment is considered as a ' $\mathrm{Go} / \mathrm{No}$ go' decision and others where several alternative investments are simultaneously considered (Buckley et al. 1978). In many cases firms will themselves investigate alternative scenarios even if this is done informally rather than through 'scenario planning'.

\section{Discussion}

Table 1 shows the areas where the four key methods identified above have been successfully applied in international business.

The application of the above principles of method suggests that a new international business history is called for that relies on the two key principles of examining change over time and using the comparative method. If we accept that the study of history is about change over time, then international business history 
Table 1 The use of historical research methods in international business

\begin{tabular}{|c|c|c|c|}
\hline & $\begin{array}{l}\text { Historical } \\
\text { research } \\
\text { method }\end{array}$ & $\begin{array}{l}\text { Areas of use in international } \\
\text { business }\end{array}$ & Examples \\
\hline \multirow[t]{4}{*}{1 . } & Source & Executive interviews & Buckley et al. (2007) \\
\hline & & Archival research & Jones (2000), Decker $(1994,2013)$ \\
\hline & & Company statements & Moss (1997) \\
\hline & & $\begin{array}{l}\text { Government policy } \\
\text { pronouncements }\end{array}$ & Buckley and Pearce 1991 \\
\hline \multirow[t]{4}{*}{2.} & $\begin{array}{l}\text { Time series } \\
\text { analyses }\end{array}$ & Long period investigations & $\begin{array}{l}\text { Kogut and Parkinson (1998) on Chandler's multi } \\
\text { division hypothesis }\end{array}$ \\
\hline & & Organisational demography & Birth and death of subsidiaries; Kogut (2009) \\
\hline & & $\begin{array}{l}\text { Computable general } \\
\text { equilibrium models }\end{array}$ & O'Rourke and Williamson (1999) \\
\hline & & Process research & $\begin{array}{l}\text { Internationalisation studies-see those reviewed } \\
\text { in Welch and Paavilainen-Mantymaki (2014) }\end{array}$ \\
\hline \multirow[t]{3}{*}{3.} & $\begin{array}{l}\text { Comparative } \\
\text { methods }\end{array}$ & $\begin{array}{l}\text { 'Natural experiment' in a } \\
\text { multinational company }\end{array}$ & $\begin{array}{l}\text { Kogut and Zander (2000) on Zeiss company in } \\
\text { East and West Germany }\end{array}$ \\
\hline & & Long run business culture & Haggerty (2012), Jones (2000) and see text \\
\hline & & $\begin{array}{l}\text { Combining comparative data: } \\
\text { historical, geographical } \\
\text { sectoral }\end{array}$ & Becuwe et al. (2012) 'the first globalization' \\
\hline \multirow[t]{3}{*}{4.} & $\begin{array}{l}\text { Counterfactual } \\
\text { analysis }\end{array}$ & $\begin{array}{l}\text { Impact of foreign direct } \\
\text { investment on host country }\end{array}$ & $\begin{array}{l}\text { Steuer (1973), Buckley and Artisien (1987) } \\
\text { (European hosts "South") }\end{array}$ \\
\hline & & $\begin{array}{l}\text { Impact of FDI on source } \\
\text { country }\end{array}$ & $\begin{array}{l}\text { Cairncross (1953) (UK), Hufbauer and Adler } \\
\text { (1968) (US), Reddaway et al. (1968) (UK), } \\
\text { Buckley and Artisien (1987) (European } \\
\text { investors 'North') }\end{array}$ \\
\hline & & Impact of railways & Fogel (1964), Casson 2009 \\
\hline
\end{tabular}

needs to take a long-run view of change and of the role of multinational firms in large scale social and economic development. This presents a major challenge in view of the material in archives. Company archives cover the world from the point of view of the (single) company. In international business this represents only one actor in a complex drama. The roles of host and source countries are perforce omitted. It behoves the writers of international company histories to take a wider perspective than just the company's viewpoint. In approaching the comparative method, the spatial comparison encompasses the international dimension but changes over time require a longer run view than most company histories allow for. Comparing the role of a company in the eighteenth century with the nineteenth is not often possible from a single company's archives (and it can be argued, were this to be so, we would be dealing with an outlier). In short, the writing of international business history needs to be more imaginative, not only in method but also in its engagement with wider theory and technique. 
It is equally the case that international business theory and methods can enrich historical research. ${ }^{12}$ In addition to the Chitu et al. (2013) examination of 'history effects' in international finance and trade, international business can be focused on global history in the way that Bell and Dale (2011) analysed the economic and financial dimensions of the medieval pilgrimage business (using contract and network theory and the analysis of saints' shrines as business franchise, under an umbrella brand of the Universal Catholic Church).

\subsection{Historical Research Approaches and the Internationalisation Process}

The question of how firm internationalisation evolves over time is best answered by the careful use of historical research methods duly adapted for the context of international business research (Jones and Zeitlin 2007). The temporal dimension of the internationalisation process needs to be centre-stage and critical decision points and turning points need to be mapped on a timeline and against feasible alternatives. As extant international business research has shown (Buckley et al. 2007), managers are only partly guided by rational processes and context and contingency play roles in determining the final decisions. If we know when these critical decisions are made, then it becomes much easier to understand the factors that were in play in the decision makers' minds. It is frequently remarked that key 'events' (a coup, the launch of a rival's product, a competitive market entry) were the triggers for investment (or non-investment) decisions and a timeline of events - a mapping of process - can be a key to understanding. The temporal sequencing of 'events' in the internationalisation process is clearly vital to comprehension of the firm's strategy and decisions. As well as time, at a given place, we need to add place at a given time for all these events. Thus a double comparative across time and space is necessary for a rounded understanding of outcomes.

Process research also needs to comprehend simultaneous processes as there is not just one sequence of events in internationalisation; rather, there are multiple. Selection of processes to track has to be theoretically driven. Process research cannot stand apart from the theory, it is has to be fully engaged with the appropriate theories and to feed back into them (Paavilainen-Mantymaki and Welch 2013). This is fully in accord with Pettigrew's (1997) approach to processual analysis. Moreover, as Pettigrew (1997, p. 340) says, 'The time quality of a processual analysis thereby lies in linking processes to outcomes'. Linking internationalisation processes to outcomes (performance) is a missing element in our understandingthe results of the managerial decisions form an essential element of a feedback loop to further internationalisation.

The four generic methods applied in historical research outlined here-source criticism, time series analysis, the use of comparative methods and counterfactual analysis - are all vital in constructing a proper process analysis of the internationalisation of the firm (or of a firm's internationalisation). It is fundamental that a critical appraisal of all sources be undertaken, be they company statements,

\footnotetext{
12 Kobrak and Schneider (2011) make a call for a renewal of historical research methods in business history, 'reviving some basic historiographical notions' (p. 401).
} 
archives, documents or interviews. Wherever possible these should be triangulated against other sources. Nothing should be taken on trust and, if it has to be, this should be clearly stated. Wherever possible, a timeline of relevant events should be made in order to sequence the decision processes and outcomes. The construction of multiple timelines - of different managers, sub-units of the firm and other key actors (such as competitors, agents, customers, suppliers, governmental bodies, support agencies) should be compared and contrasted. The coincidence in time of actions by interested parties is prima facie evidence of joint causality. These techniques can be extended by the use of comparisons not only in time but in space. The geographical mapping of actions and outcomes gives richness to the process analysis. The transmission and impact of decisions from one geographical point (e.g., headquarters) to another (a subsidiary, a potential takeover victim), the time-lags involved and the reaction time of the recipient are all vital in understanding internationalisation. Counterfactual analysis, too, can be a useful tool. Firms often approach internationalisation decisions with a number of contingencies. If they cannot acquire foreign firm $\mathrm{X}$, should they turn to $\mathrm{Y}$, or to a greenfield venture instead? These alternatives are useful to know and it may be possible to construct feasible alternative internationalisation paths.

In summary, historical research methods and approaches provide a research design for internationalisation process studies that enhance the depth of understanding by incorporating concrete timelines, alternatives and decision processes.

\subsection{A New Concept of Internationalisation}

The new concept of internationalisation that emerges from a consideration of the light shed by historical research on managerial processes is that internationalisation is the outcome of a set of decisions, dependent on context and previous decisions, considering alternative locations, entry and development methods in a choice set of time and space. In these sequential decisions, knowledge of past decisions and their outcomes plays a part in the next round of decisions. Hence companies can create 'vicious circles' or 'virtuous circles' in their internationalisation processes. In this sense, a knowledge of history of the company making the decision and of similar companies making comparable decisions can be valuable for the manager. History matters to decision-makers as well as analysts. The question of when to take history into account and when to ignore it and 'take a chance' is the essence of managerial judgement (and of 'real options theory' — see Kogut and Kulatilaka 2001; Buckley et al. 2002). Those who make regular correct calls will develop a 'track record' and be valued accordingly. Thus both the weight of history and the judgement of successful individuals will build path dependence into the internationalisation process.

The research approach formulated in this article encompasses the Uppsala approach to internationalisation (Johanson and Vahlne 1977, 2009) as a special case. The Uppsala approach has no explicit role for time. It explains market entry as a sequence which is determined by psychic proximity to the source country in a loose path dependent fashion. A more careful specification of the relationship between market entry and psychic distance and an explicit acknowledgement of the 
role of time would allow a fully historical analysis of market entry sequencing in the Uppsala tradition.

\section{Conclusion: The Response to the Challenge of Historical Research}

The last sentences of Butterfield's (1965, p. 132) The Whig Interpretation of History encompasses the challenge of historical research methods: 'In other words, the truth of history is no simple matter, all packed and parcelled ready for handling in the market-place. And the understanding of the past is not so easy as it is sometimes made to appear'. Historical research methods can help international business researchers to be more questioning, analytical and critical and to think laterally in terms of alternative states of the world, different choices and outcomes. There is a justifiable argument that international business research is insufficiently critical of 'texts' in all their forms-company statements, official statistics, interviews with managers among them-and historical research has a number of techniques for improving the penetration of meaning behind texts, as this piece has shown.

In using research methods derived from history we must always factor in 'Contingency, choice and agency' (Clark 2012, p. 362). We should also remember that history interacts with geography-context is crucial. To quote the historian Peter Brown's work on wealth in the early Christian period, 'A true history of Latin Christianity requires an unremitting sense of place' (Brown 2012, p. xxii). A good example relevant to international business is the combined use of historical, geographical and sectoral data by Becuwe, Blancheton and Charles (2012) in analysing the decline of French trade power in the 'first globalization' of 1850-1913. A sense of place involves understanding both the global macro context and the particular location.

There is an awkward disjunction between traditional historical research and hypothetico-deductive modelling. This is paralleled by the lack of integration between quantitative and qualitative methods in international business research, arising from their philosophical bases in positivism and subjectivism. The careful integration of historical research methods into international business provides us with one channel of progress towards a more complete understanding of the phenomena of international business.

In the particular case of the analysis of the internationalisation of the firm, historical approaches place managerial judgement central to the process. Such judgement, however, is constrained by context. This context is both temporal and spatial. 'When' and 'where' matter in both an individual decision and the analysis of decisions. The use of the plural here implies sequencing and therefore a focus on process. The choice set faced by the manager is constrained by what has gone before-by history. This does not determine the next decision in the sequence but it influences it. The new concept of internationalisation is that sequence, not events, are at the heart of the international growth of the firm, that spatial issues (including psychic distance to a potential host country) must be accounted for, and that past decisions constrain outcomes. 
On the importance of methodology (in international business as elsewhere) we can end with a quote from Kogut (2009, p. 711): 'It is one of the best-kept secrets of research that a methodological contribution is the most powerful engine for the replication and diffusion of an idea'.

Acknowledgments I am grateful for comments on earlier versions from Chris Clark (Cambridge), Simon Ball (Leeds), Andrew Thompson (Exeter), Niall Ferguson (Harvard), Jeremy Black (Exeter), Mark Casson (Reading), Janet Casson (Oxford), Catherine Casson (Birmingham), Jonathan Steinberg (Pennsylvania), Catherine Welch (Sydney), Adrian Bell (Reading), Peter Miskell (Reading), Stephanie Decker (Aston), Geoffrey Jones (Harvard), Mira Wilkins (Florida International University), an anonymous reviewer for the AIBUK 2013 Conference at Aston University, participants at AIBUK Aston 2013, three anonymous reviewers for AIB 2013 and participants at the AIB Conference, Istanbul, July 2013, two anonymous referees and particularly to the editors of this Focused Issue.

Open Access This article is distributed under the terms of the Creative Commons Attribution 4.0 International License (http://creativecommons.org/licenses/by/4.0/), which permits unrestricted use, distribution, and reproduction in any medium, provided you give appropriate credit to the original author(s) and the source, provide a link to the Creative Commons license, and indicate if changes were made.

\section{References}

Barthes, R. (2005). Criticism and truth. Translated and edited by K. P. Keueman. London: Continuum International Publishing Group.

Beatty, J. (2011). The lost history of 1914: How the Great War was not inevitable. London: Bloomsbury. Becuwe, S., Blancheton, D., \& Charles, L. (2012). The decline of French trade power during the first globalization (1850-1913) (pp. 2012-2022). Cahiers du Gretha: Université de Bordeaux.

Belich, J. (2009). Replenishing the earth: The settler revolution and the rise of the Angle-World 1783-1939. Oxford: Oxford University Press.

Bell, A. R., \& Dale, R. S. (2011). The medieval pilgrimage business. Enterprise and Society, 12(3), 601-627.

Berlin, I. (1960). History and theory. The concept of scientific history. History and Theory, 1(1), 1-31.

Bloch, M. (1954). The historian's craft. Translated Peter Putman. Manchester: Manchester University Press.

Boole, G. (2003). [1854] An investigation of the laws of thought, on which are founded the mathematical theories of logic and probabilities. Amherst: Prometheus Books.

Brown, P. (2012). Through the eye of a needle: Wealth, the fall of Rome and the making of Christianity in the West 350-550 AD. Princeton: Princeton University Press.

Buckley, P. J., \& Artisien, P. (1987). North-south direct investment in the European communities: The employment impact of direct investment by British, French and German multinationals in Greece, Portugal and Spain. Basingstoke: Macmillan.

Buckley, P. J., Casson, M. C., \& Gulamhussen, M. A. (2002). Internationalisation-Real options, knowledge management and the Uppsala Approach. In V. Havila, M. Forsgren, \& H. Hakansson (Eds.), Critical perspectives on internationalisation (pp. 229-261). Oxford: Elsevier.

Buckley, P. J., Devinney, T. M., \& Louviere, J. J. (2007). Do managers behave the way theory suggests? A choice-theoretic examination of foreign direct investment location decision-making. Journal of International Business Studies, 38(7), 1069-1094.

Buckley, P J., Newbould, G. D., \& Thurwell, J. (1978). Going international-The experience of smaller companies overseas. London: Associated Business Press/New York: Halsted Press.

Buckley, P. J., Pass, C. L., \& Prescott, K. (1992). Servicing international markets: Competitive strategies of firms. Oxford: Basil Blackwell.

Buckley, P. J., \& Pearce, R. D. (1991). International aspects of UK economic activities: Reviews of UK statistical sources. Review No 44, Volume XXVI Royal Statistical Society/Economic and Social Research Council. London: Chapman and Hall. 
Burgelman, R. A. (2011). Bridging history and reductionism: A key role for longitudinal qualitative research. Journal of International Business Studies, 42(5), 591-601.

Butterfield, H. (1965). The Whig interpretation of history. New York: W. W. Norton \& Company Inc. (Original 1931).

Cairncross, A. (1953). Home and foreign investment. Cambridge: Cambridge University Press.

Cannadine, D. (2013). The undivided past: History beyond our differences. London: Allen Lane.

Casson, M. (2009). The world's first railway system. Oxford: Oxford University Press.

Chandler, A. D. (1962). Strategy and structure: Chapters in the history of the American industrial enterprise. Cambridge: MIT Press.

Chandler, A. D. (1984). Comparative business history. In D. C. Coleman \& P. Mathias (Eds.), Enterprise and history: Essays in honour of Charles Wilson (pp. 473-503). Cambridge: Cambridge University Press.

Chitu, L., Eichengreen, B., \& Mehl, A. J. (2013). History, gravity and international finance. National Bureau of Economic Research Working paper 18697, Washington D.C.

Clark, C. (2012). The sleepwalkers: How Europe went to war in 1914. London: Allen Lane.

Clark, P., \& Rowlinson, M. (2004). The treatment of history in organisation studies: Towards an 'historic turn'? Business History, 43(3), 331-352.

Collier, D., Brady, H. E., \& Seawright, J. (2010). Sources of leverage in causal inference: Towards an alternative view of methodology. In H. E. Brady \& D. Collier (Eds.), Rethinking social enquiry: Diverse tools, shared standards (2nd ed., pp. 229-266). New York: Rowman and Lillefield.

Cowley, R. (Ed.). (1999). What if?. New York: G.P. Putnam's Sons.

Deaton, A. (2009). Instruments of development: Randomization in the tropics, and the search for the elusive keys to economic development. The Keynes Lecture. London: British Academy.

Decker, S. (2013). The silence of the archive: Post-colonialism and the practice of historical reconstruction from archival evidence. Management and Organisational History, 8(2), 155-173.

Derrida, J. (1994). Specters of Marx. Translated Peggy Kamuf. New York: Routledge.

Diebolt, C. (2012). The cliometric voice. Association Française de Cliométrie. Working paper No. 12.

Dunning, T. (2012). Natural experiments in the social sciences. Cambridge: Cambridge University Press.

Durand, R., \& Vaara, E. (2009). Causation, counterfactuals and competitive advantage. Strategic Management Journal, 30(12), 1245-1264.

Easterlin, R. A. (2013). Cross sections are history. IZA discussion paper No. 7341.

Evans, L. J. (2014). Altered pasts: Counterfactuals in history. London: Little, Brown.

Ferguson, N. (Ed.). (1997). Virtual history: Alternatives and counterfactuals. London: Picador.

Fogel, R. W. (1964). Railroads and American economic growth: Essays in econometric history. Baltimore, Maryland: The Johns Hopkins Press.

Foucault, M. (1965). Madness and civilization. Translated R. Howard. New York: Pantheon.

Freedman, D., Pisani, R., \& Purves, R. (2007). Statistics (4th ed.). New York: W. W. Norton Inc.

Gaddis, J. L. (2002). The landscape of history: How historians map the past. Oxford: Oxford University Press.

Gottschalk, L. (1950). Understanding history: A primer of historical method. New York: Alfred A Knopf.

Gramsci, A. (1973). Selections from the prison notebooks. Edited by Q. Hoare and G. Nowell Smith. New York: International Publishers.

Granger, C. W. J. (1988). Causality, cointegration and control. Journal of Economic Dynamics and Control, 12(2), 551-559.

Granger, C. W. J., \& Newbold, P. (1974). Spurious regressions in econometrics. Journal of Econometrics, 2(2), 111-120.

Green, W. A. (1993). History, historians and the dynamics of change. Westport: Praeger.

Gregory, B. S. (2012). The unintended reformation: How a religious revolution secularized society. Cambridge: Belking Press of Harvard University.

Grimmer-Solem, E. (2003). The rise of historical economics and social reform in Germany 1864-1894. Oxford: Oxford University Press.

Haggerty, S. (2012). 'Merely for money?' Business culture in the British Atlantic 1750-1815. Liverpool: Liverpool University Press.

Hannah, L. (2007). The 'divorce' of ownership from control from 1900 onwards: Re-calibrating imagined global trends. Business History, 49(4), 404-438.

Hofstede, G. (1991). Cultures and organisations: Software of the mind. London: McGraw Hill.

Hofstede, G. (1997). Cultures and organisations: Software of the mind. New York: McGraw-Hill. 
Hofstede, G. (2001). Culture's consequences: Comparing values, behaviours, institutions and organisations across nations (2d ed.). New York: Sage Publications.

Hood, N., \& Young, S. (1979). The economics of international business. London: Longman.

Hufbauer, G. C., \& Adler, F. (1968). US manufacturing investment and the balance of payments. Washington, DC: US Treasury Department.

Hymer, S. H. (1976). The international operations of national firms: Study of foreign direct investment. Cambridge: MIT Press.

Jackson, J. E., \& Kollman, K. (2010). A formulation of path dependence with an empirical example. Quarterly Journal of Political Science, 5(3), 257-289.

Johanson, J., \& Vahlne, J. E. (1977). The internationalization process of the firm: A model of knowledge development and increasing foreign market commitments. Journal of International Business Studies, 8(1), 23-32.

Johanson, J., \& Vahlne, J. E. (2009). The Uppsala internationalization process model revisited: From liability of foreignness to liability of outsidership. Journal of International Business Studies, 40(9), 1411-1431.

Jones, G. (1998). Company history and business history in the 1990s. University of Reading discussion papers in economics and management (series A), p. 383.

Jones, G. (2000). Merchants to multinationals. British trading companies in the nineteenth and twentieth centuries. Oxford: Oxford University Press.

Jones, G., \& Khanna, T. (2006). Bringing history (back) into international business. Journal of International Business Studies, 37(4), 453-468.

Jones, G., \& Zeitlin, J. (Eds.). (2007). The Oxford handbook of business history. Oxford: Oxford University Press.

Judge, W. Q., Fainshmidt, S., \& Brown, J. L. (2014). Which model of capitalism best delivers both wealth and equality? Journal of International Business Studies, 45(4), 363-386.

Kipping, M., Wadhwani, R. D., \& Bucheli, M. (2014). Analyzing and interpreting historical sources: A basic methodology. In M. Bucheli \& R. D. Wadhwani (Eds.), Organizations in time: History, theory, methods (pp. 305-329). Oxford: Oxford University Press.

Kobrak, C., \& Schneider, A. (2011). Varieties of business history: Subject and methods for the twentyfirst century. Business History, 53(3), 401-424.

Kogut, B. (2009). Methodological contributions in international business and the direction of academic research activity. In A. Rugman (Ed.), The Oxford handbook of international business (2nd ed., pp. 711-739). Oxford: Oxford University Press.

Kogut, B., \& Kulatilaka, N. (2001). Capabilities as real options. Organization Science, 12(6), 744-758.

Kogut, B., \& Parkinson, D. (1998). Adoption of the multidivisional structure: Analysing history from the start. Industrial and Corporate Change, 7(2), 249-273.

Kogut, B., \& Zander, U. (2000). Did socialism fail to innovate? A natural experiment of the two Zeiss companies. American Sociological Review, 65(2), 169-190.

Laidler, D. (2012). Today's standards and yesterday's economics-two short occasional essayseliminating history from economic thought and Mark Blaug on the quantity theory. Economic Policy Research Institute working paper series 2012-6, University of Western Ontario.

Lebow, R. N. (2012). Counterfactual thought experiments: A necessary teaching tool. The History Teacher, 40(2), 153-176.

Lebow, R. N. (2014). Archduke Franz, Ferdinand lives!. New York: Palgrave Macmillan.

Leunig, T. (2010). Social savings. Journal of Economic Surveys, 24(5), 775-800.

Ludden, D. (Ed.). (2001). Reading subaltern studies: Critical history, contested meaning and the globalization of South Asia. London: Anthem Press.

MacKay, R. B. (2007). 'What if': Synthesising debates and advancing prospects of using virtual history in management and organization theory. Management \& Organizational History, 2(4), 295-314.

Mahoney, J. (2004). Comparative-historical methodology. Annual Review of Sociology, 30, 81-101.

Maielli, G., \& Booth, C. (2008). Counterfactual history, management and organizations: Reflections and new directions. Management \& Organizational History, 3(1), 49-61.

Moss, M. (1997). Archives, the historian and the future. In M. Bentley (Ed.), Companion to historiography (pp. 960-973). London: Routledge.

Nickell, S. (1981). Biases in dynamic models with fixed effects. Econometrica: Journal of the Econometric Society, 49(6), 1417-1426.

O'Rourke, K., \& Williamson, G. (1999). Globalization and history: The evolution of a nineteenth-century Atlantic economy. Cambridge: MIT Press. 
Oz, O. (2004). Using Boolean-and fuzzy-logic-based methods to analyse multiple case study evidence in management research. Journal of Management Inquiry, 13(2), 166-179.

Paavilainen-Mäntymäki, E., \& Welch, C. (2013). How to escape an unprocessual legacy? A viewpoint from international business research. In M. E. Hassett \& E. Paavilainen-Mäntymäki (Eds.), Handbook of longitudinal research methods in organisation and business studies (pp. 229-248). Cheltenham: Edward Elgar.

Page, S. E. (2006). Path dependence. Quarterly Journal of Political Science, 1(1), 87-115.

Penrose, E. T. (1959). The theory of the growth of the firm. Oxford: Basil Blackwell.

Pettigrew, A. M. (1997). What is processual analysis? Scandinavian Journal of Management, 13(4), 337-348.

Ragin, C. C. (1987). The comparative method: Moving beyond qualitative and quantitative strategies. Berkeley: University of California Press.

Reddaway, W. B., et al. (1968). Effects of UK direct investment overseas: Final report. Cambridge: Cambridge University Press.

Rowlinson, M., Toms, S., \& Wilson, J. F. (2007). Competing perspectives on the 'managerial revolution': from 'managerialist' to 'anti-managerialist'. Business History, 49(4), 464-482.

Saka-Helmhout, A. (2011). Comparative historical analysis in international management research. In R. Piekkari \& C. Welch (Eds.), Rethinking the case study in international business and management research (pp. 383-407). Cheltenham: Edward Elgar.

Schwarzkopf, S. (2012). Why business historians need a constructive theory of the archive. Business Archives, 105(November), 1-9.

Shaver, J. M. (1998). Accounting for endogeneity when assessing strategy performance: Does entry mode choice affect FDI survival? Management Science, 44(4), 571-585.

Simiand, F. J. (1903). Méthode historique et sciences socials. Revue de Synthèse Historique, 6, 1-22.

Skocpol, T., \& Somers, M. (1980). The uses of comparative history in macrosocial inquiry. Comparative Studies in Society and History, 22(2), 174-197.

Snyder, T. (2010). Bloodlands: Europe between Stalin and Hitler. London: The Bodley Head.

Steuer, M.D. et al. (1973). The impact of foreign direct investment on the U.K. London: HMSO.

Stinchcombe, A. L. (1965). Social structure and organisations. In J. G. March (Ed.), Handbook of organizations (pp. 142-193). Chicago: Rand-McNally.

Tilley, C. (1983). Big structure, large processes, huge comparisons. New York: Russell Sage Foundation.

Toms, S., \& Beck, M. (2007). The limitations of economic counterfactuals: The case of the Lancashire textile industry. Management \& Organizational History, 2(4), 315-330.

Welch, C., \& Paavilainen-Mäntymäki, E. (2014). Putting process (back) in: Research on the internationalization process of the firm. International Journal of Management Reviews, 16(1), 2-23.

Whittington, R. (2007). Introduction: Comparative perspectives on the managerial revolution. Business History, 49(4), 399-403.

Wilkins, M., \& Hill, F. E. (2011). American business abroad: Ford on six continents. Cambridge: Cambridge University Press (Original edition 1964 Wayne State University Press).

Yin, R. K. (2014). Case study research: Design and methods (5th ed.). Thousand Oaks: Sage Publications.

Zaheer, S. (1995). Overcoming the liability of foreignness. Academy of Management Journal, 38(2), 341-363.

Zeitlin, J. (2007). The historical alternatives approach. In G. Jones \& J. Zeitlin (Eds.), The Oxford handbook of business history (pp. 120-140). Oxford: Oxford University Press. 